\title{
PENGEMBANGAN FUN TAX BERBASIS ULAR TANGGA SEBAGAI MEDIA PEMBELAJARAN ADMINISTRASI PAJAK SISWA KELAS XI AKUNTANSI SMK NEGERI 1 DEPOK YOGYAKARTA
}

\author{
THE DEVELOPMENT OF FUN TAX BASED ON SNAKE AND LADDER AS TAX \\ ADMINISTRATION LEARNING MEDIA ACCOUNTING STUDENTS OF GRADE XI \\ AT SMK NEGERI 1 DEPOK YOGYAKARTA
}

\author{
Oleh: \\ Luthfi Nurlaily \\ Prodi Pendidikan Akuntansi Universitas Negeri Yogyakarta \\ lnurlaily@gmail.com
}

$\underline{\text { Isroah }}$

Staf Pengajar Jurusan Pendidikan Akuntansi Universitas Negeri Yogyakarta

\begin{abstract}
Abstrak
Penelitian ini bertujuan untuk, 1) mengembangkan Fun Tax berbasis Ular Tangga sebagai media pembelajaran Administrasi Pajak siswa Kelas XI Akuntansi SMK Negeri 1 Depok Yogyakarta. 2) mengetahui penilaian terhadap kelayakan Fun Tax berbasis Ular Tangga. Penilaian kelayakan tersebut meliputi Ahli Materi, Ahli Media, Guru, dan Siswa.

Penelitian pengembangan ini dilakukan dengan menggunakan model Four-D (4D). Subjek dalam penelitian ini adalah ahli materi, ahli media, guru, serta siswa SMK Negeri 1 Depok Yogyakarta. Objek penelitian ini adalah Fun Tax berbasis Ular Tangga. Teknik pengumpulan data dalam penelitian ini adalah melalui angket. Data yang diperoleh dari angket kemudian dianalisis secara deskriptif kualitatif dan kuantitatif.

Hasil penelitian ini adalah: 1) Tahapan dalam pengembangan Fun Tax berbasis Ular Tangga ini meliputi empat tahap, yaitu: (1) Define, dengan melakukan observasi, wawancara, dan analisis kebutuhan yang meliputi, analisis kurikulum, analisis karakteristik siswa, analisis materi, dan merumuskan tujuan. (2) Design, yaitu dengan menetapkan media pembelajaran yang akan dikembangkan, merancang penyajian media, dan pembuatan media pembelajaran Fun Tax yang terdiri dari perancangan konsep Fun Tax, penyusunan materi Pajak Penghasilan, serta penyusunan instrumen angket penilaian produk. 3) Develop, media Fun Tax dinilai oleh para validator yang terdiri dari Ahli Materi, Ahli Media, dan Guru. Pada tahap ini juga dilakukan uji pengembangan terhadap siswa. (4) Disseminate, media Fun Tax telah disebarkan di SMK YPKK 2 Sleman dan SMK Sriwijaya 2 Wangon. 2) Hasil penelitian menunjukkan bahwa tingkat kelayakan Fun Tax berbasis Ular Tangga sebagai media pembelajaran Administrasi Pajak berdasarkan penilaian ahli materi diperoleh rata-rata skor 4,5 yang termasuk dalam kategori Sangat Layak, ahli media diperoleh rata-rata skor 4,55 yang termasuk dalam kategori Sangat Layak, guru Administrasi Pajak diperoleh rata-rata 4,76 yang termasuk kategori Sangat Layak, dan uji pengembangan oleh siswa sebesar 4,26 yang termasuk dalam kategori Sangat Layak.
\end{abstract}

Kata Kunci: Fun Tax, Ular Tangga, Media Pembelajaran

\begin{abstract}
This study aims to 1) develop Fun Tax based on Snake and Ladder as a learning media of accounting students ofgrade XI at SMK Negeri 1 Depok Yogyakarta. 2) to know the feasibility of Fun
\end{abstract}


Tax based on Snake and Ladder. The feasibility assessments include the assessment of material expert, media expert, teacher, and students.

This research and development applied Four-D (4D) model. The subjects of this research were material expert, media expert, teacher, and students of SMK Negeri 1 Depok Yogyakarta. Meanwhile, the object of this research was Fun Tax of based on Snake and Ladder. The data collection technique was questionnaires. The data obtained from questionnaires were analyzed qualitatively and quantitatively.

The results of this research are: 1) the development of Fun Tax based on Snake and Ladder includes four stages: (1) Define, by conducting an observation, interview, and need analysis which include curriculum analysis, students character analysis, material analysis, and formulating goals; 2) Design, by deciding the learning media would be developed, arranging media presentation, and creating the learning media of Fun Tax which consisted of planning the concept of the Fun Tax, arranging the materials of income tax, and arranging the instrument of the research which was the questionnaires of product assessment; 3) Develop, by assessing the media Fun Tax by the validators which were material expert, media expert, teacher, and students; and 4) Disseminate, by distributing the media Fun Tax in SMK YPKK 2 Sleman and SMK Sriwijaya 2 Wangon. 2) The results show that the feasibility level of Fun Tax based on Snake and Ladder as thelearning media according to expert material judgment obtained an average score 4,5 which include in the category of Totally Feasible, media expert obtained an average score of 4,55 included in the category of Totally Feasible, Tax Administration teacher an average score of 4,76 was included in the Totally Feasible category, and development test of students 4,26 included in the Totally Feasible category.

Keywords: Fun Tax, Snake and Ladder, Learning Media.

\section{PENDAHULUAN}

Berdasarkan data yang dikeluarkan oleh United Nations Educational, Scientific and Cultural Organization (UNESCO), Indonesia meraih nilai indeks pembangunan pendidikan atau Educational for All Development Index (EDI) sebesar 0,945 pada tahun 2015. Perolehan indeks tersebut menempatkan Indonesia pada peringkat ke54 dari 92 negara. Rendahnya kualitas pendidikan di Indonesia dipengaruhi oleh berbagai faktor. Salah satu faktor yang memberikan dampak cukup luas pada proses pembelajaran adalah rendahnya kualitas pendidik, karena yang bertugas untuk merencanakan dan melaksanakan proses pembelajaran adalah seorang pendidik itu sendiri. UU Republik Indonesia Nomor 20 Tahun 2003 tentang Sistem Pendidikan Nasional menyebutkan bahwa seorang pendidik mempunyai kewajiban untuk menciptakan suasana pendidikan yang bermakna, menyenangkan, kreatif, dinamis dan dialogis sehingga dapat meningkatkan mutu pendidikan. Kewajiban tersebut akan selaras dijalankan apabila didukung oleh sumber-sumber daya pendukung.

Beberapa sumber daya pendukung yang perlu diperhatikan antara lain berupa strategi pembelajaran, sumber belajar serta media pembelajaran. Penggunaan media pembelajaran sangat penting dalam proses belajar dan mengajar. Hal ini karena media pembelajaran sangat membantu guru atau pengajar dalam memberikan pengajaran secara maksimal. Ahsan (2008) dalam Jurnal yang berjudul Use of Media for Effective Instruction its Importance: Some Consideration juga menjelaskan bahwa penggunaan media pembelajaran akan membuat kegiatan pembelajaran menjadi lebih efektif dan efisien.

Pembelajaran merupakan sebuah sistem, karena di dalamnya memiliki komponen-komponen yang saling berkaitan dalam rangka mencapai tujuan yang ditentukan. Komponen tersebut terdiri atas tujuan, materi, metode, media, dan evaluasi. Masing-masing komponen tersebut saling berkaitan dan merupakan satu kesatuan yang tidak terpisahkan. Guru harus 
menggunakan media yang terbaik untuk memfasilitasi pembelajaran atau meningkatkan pemahaman siswa terhadap materi pengajaran. Dengan demikian, melalui penggunaan media pembelajaran, diharapkan siswa akan lebih mudah dalam memahami materi yang disampaikan oleh guru.

Macam-macam media pembelajaran diantaranya adalah buku, powerpoint, video, gambar, poster, grafik, film, animasi, kaset, televisi, komputer, dan permainan. Berbagai macam media pembelajaran tersebut memiliki keunggulan dan kelemahan masing-masing jika diterapkan dalam proses pembelajaran. Oleh karena itu, ketepatan dalam memilih media yang sesuai dengan materi yang diajarkan akan menentukan keberhasilan belajar dan ketercapaian tujuan belajar yang telah ditentukan sebelumnya.

Penggunaan media dalam proses pembelajaran belum optimal diterapkan di berbagai lembaga pendidikan. Salah satu lembaga tersebut adalah SMK Negeri 1 Depok. SMK Negeri 1 Depok merupakan salah satu Sekolah Menengah Kejuruan di Kabupaten Sleman, provinsi Daerah Istimewa Yogyakarta yang beralamat di Ring Road Utara Maguwoharjo Depok Sleman Yogyakarta. Sekolah ini memiliki empat program keahlian yaitu: Program Keahlian Akuntansi, Program Keahlian Administrasi Perkantoran, Program Keahlian Pemasaran, dan Program Keahlian Tata Busana.

Mata Pelajaran Administrasi Pajak merupakan mata pelajaran yang wajib ditempuh dan tuntas bagi siswa kelas XI dan XII program keahlian Akuntansi. Ruang lingkup materi Administrasi Pajak kelas XI Akuntansi terdiri dari banyak teori dan sedikit praktik, sedangkan kelas XII Akuntansi lebih banyak melakukan praktik menghitung pajak.

$\begin{array}{crr}\text { Berdasarkan wawancara } & \text { yang } \\ \text { dilakukan peneliti } & \text { dengan guru }\end{array}$ Administrasi Pajak pada bulan November 2017, Administrasi Pajak merupakan salah satu mata pelajaran yang cukup sulit diikuti oleh siswa kelas XI Akuntansi. Siswa kelas XI Akuntansi mengalami kesulitan dalam memahami materi berkarakteristik teori, sebagaimana materi Administrasi Pajak yang mereka dapatkan di kelas XI. Adapun materi yang cukup mendasar namun dirasa sulit adalah materi umum Pajak Penghasilan. Siswa mengungkapkan bawa materi berkarakteristik perhitungan jauh lebih mudah untuk dikerjakan, namun materi berkarakteristik teori memerlukan waktu yang lebih untuk diikuti dan dipahami. Materi tersebut akan lebih mudah dipahami oleh siswa, apabila guru menggunakan media pembelajaran yang menarik, mampu membangkitkan semangat belajar, dan dapat melibatkan siswa secara langsung.

Berdasarkan observasi dan wawancara dengan guru Administrasi Pajak mengenai penggunaan media dalam proses pembelajaran, ruang-ruang kelas yang ada di SMK Negeri 1 Depok sudah dilengkapi dengan LCD. Selama ini guru lebih banyak menggunakan power point, buku, latihan soal, dan sekilas video sebagai media dalam pembelajaran. Kegiatan belajar mengajar yang satu arah cenderung membuat siswa merasa bosan. Hal itu ditandai dengan adanya berbagai kegiatan diluar pelajaran yang dilakukan para siswa saat pembelajaran berlangsung. Fakta tersebut menunjukkan kurang antusiasnya siswa dalam menyimak dan kurang inovatifnya guru dalam menyampaikan materi. Guru juga memaparkan bahwa saat ini sekolah belum mampu menyediakan dan mengembangkan media pembelajaran yang sesuai dengan kebutuhan siswa, sehingga seluruh kreativitas diserahkan kepada guru dalam mengemas pembelajaran.

Penggunaan media pembelajaran penting bagi guru dalam proses pembelajaran, karena media akan membantu guru dalam menyampaikan materi kepada siswa. Materi dalam mata pelajaran Administrasi Pajak tentunya akan lebih mudah dipahami oleh siswa jika guru 
menyampaikannya dengan menggunakan media pembelajaran yang menarik dan sesuai dengan kondisi siswa. Namun, selama ini guru dalam menyampaikan materi masih menggunakan media pembelajaran yang seringkali monoton. Oleh karena itu, guru perlu mengadakan pengembangan media pembelajaran yang lebih menarik dan sesuai karakteristik siswa. Siswa kelas XI Akuntansi SMK Negeri 1 Depok menyukai hal-hal baru, sehingga mudah merasa bosan dengan sesuatu yang cenderung seperti biasanya, siswa juga sangat kompak namun kompetitif.

Sebagaimana tugas guru sebagai pendidik yakni harus mampu menciptakan kondisi pembelajaran yang kreatif dan menyenangkan. Pembelajaran yang kreatif dan menyenangkan tersebut dapat dilakukan guru melalui berbagai cara. Salah satu cara yang dapat dilakukan adalah dengan penggunaan media dalam pembelajaran (Sadirman, 2011:164). Penggunaan media dapat memungkinkan hal-hal yang tidak mungkin dihadirkan dalam proses pembelajaran menjadi mungkin dihadirkan. Media yang interaktif juga mampu membantu siswa dalam meningkatkan aktivitas belajarnya, misalnya menjawab pertanyaan.

Salah satu media pembelajaran yang dapat dikembangkan dan menyenangkan adalah media berbasis permainan. Permainan merupakan aktivitas yang dilakukan seseorang untuk mencapai suatu kesenangan, atau kegembiraan, serta kepuasan. Pengembangan media berbasis permainan akan mendorong siswa merasakan kesenangan layaknya mereka bermain namun materi pelajaran tetap tersampaikan. Hastead (dalam Shah, 2017: 22) menyatakan bahwa "the use of game in education is thought to promote higher levels of engagement and motivation amongs students, and subsequently on student achievement."

Berbagai jenis permainan telah diciptakan, salah satunya berbentuk permainan papan. Permainan papan adalah permainan yang dimainkan di atas papan dengan beberapa bagian, dapat berupa kotak, lingkaran, atau bentuk lainnya yang digunakan sebagai tempat bermain. Beberapa contoh permainan tersebut adalah catur, dam, scrabble, monopoli, tic-tac-toe, ular tangga, dan lain sebagainya. Adapun salah satu bentuk variasi media pembelajaran Administrasi Pajak yang dapat dikembangkan adalah Fun Tax berbasis ular tangga. Ular tangga merupakan permainan papan yang sudah ada sejak lama dan sudah familiar serta sering dimainkan oleh siswa. Pengembangan media pembelajaran berkonsep ular tangga akan meningkatkan aktivitas belajar siswa dan menjadikan pembelajaran menjadi lebih menyenangkan. Media pembelajaran ular tangga dikembangkan karena memiliki keunggulan dibandingkan media pembelajaran yang lain, yaitu (1) permainan adalah sesuatu yang menyenangkan untuk dilakukan dan menghibur, (2) permainan memungkinkan adanya partisipasi aktif siswa untuk belajar, (3) permainan dapat memberikan umpan balik langsung, (4) permainan memungkinkan penerapan konsep ataupun peran-peran ke dalam situasi peranan yang sebenarnya di masyarakat, (5) permainan bersifat luwes, (6) permainan dapat dengan mudah dibuat dan diperbanyak (Arief $\mathrm{S}$ Sadiman dkk., 2011:78). Disamping itu Fun Tax berbasis ular tangga dikembangkan karena praktis dalam penggunaannya, dapat dimainkan dimana saja, baik di dalam maupun di luar kelas. Fun Tax memiliki inovasi yakni tidak hanya mengandung materi namun juga terdapat variasi soal, sehingga guru dapat memahami sejauh mana siswa memahami materi. Fun Tax sebagai media pembelajaran Administrasi Pajak juga akan membuat suasana belajar menjadi menyenangkan karena siswa akan lebih semangat dalam menjawab berbagai soal terkait Administrasi Pajak yang disajikan dalam bentuk permainan. Adanya media pembelajaran Fun Tax berbasis ular 
tangga akan menjadikan siswa lebih aktif, kreatif, senang, dan tertantang dalam mengikuti pembelajaran Administrasi Pajak.

Berdasarkan uraian di atas, maka peneliti tertarik untuk mengembangkan sebuah media pembelajaran melalui penelitian dengan judul "Pengembangan Fun Tax Berbasis Ular Tangga sebagai Media Pembelajaran Administrasi Pajak Siswa Kelas XI Akuntansi SMK Negeri 1 Depok Yogyakarta".

\section{METODE PENELITIAN}

\section{Desain Penelitian}

Penelitian ini merupakan penelitian pengembangan (Research and Development) dengan menggunakan model 4D yang dikembangkan oleh Tiagarajan dan Semmel. Terdapat 4 tahapan dalam penelitian pengembangan model Four-D yaitu tahap Pendefinisian (Define), Perancangan (Design), Pengembangan (Develop), dan Penyebaran (Disseminate).

\section{Tempat dan Waktu Penelitian}

Penelitian ini dilaksanakan di kelas XI Akuntansi 1 SMK Negeri 1 Depok yang beralamat di Jalan Ring Road Utara, Maguwoharjo, Depok, Sleman, Daerah Istimewa Yogyakarta pada bulan Januari sampai dengan Juli 2018.

\section{Subjek dan Objek Penelitian}

Subjek penelitian ini adalah siswa kelas XI Akuntansi 1 SMK Negeri 1 Depok yang dipilih, terdiri dari 28 siswa dan 3 validator yang terdiri dari 1 Ahli Media dan 1 ahli materi (Dosen Jurusan Pendidikan Akuntansi), serta 1 Praktisi (Guru Akuntansi). Objek dalam penelitian ini adalah Fun Tax sebagai media pembelajaran Administrasi Pajak SMK.

\section{Prosedur Penelitian}

Penelitian pengembangan media ini menggunakan desain penelitian pengembangan model 4D (Four-D Models) oleh Thiagarajan dan Semmel (1974). Penelitian yang dilakukan dalam penelitian pengembangan ini terdiri atas 4 (empat) tahap utama, yaitu: (1) Define (pendefinisian); (2) Design (perancangan); (3) Develop (pengembangan);

Disseminate (penyebaran). Kegiatankegiatan yang dilakukan pada setiap tahap model 4D yang dikembangkan oleh Thiagarajan (Endang Mulyatiningsih, 2011: 179), dapat dijelaskan sebagai berikut:

a. Tahap Define (Pendefinisian)

Tahap Define bertujuan untuk menetapkan dan mendefinisikan syaratsyarat pengembangan. Pada pengembangan Fun Tax, tahap pendefinisian dilakukan dengan 4 cara, yaitu (1) analisis kurikulum, (2) analisis karakteristik siswa, (3) analisis materi, dan (4) merumuskan tujuan.

b. Tahap Design (Perancangan)

Tahap perancangan ini dilaksanakan setelah analisis kebutuhan selesai. Tahap ini dilakukan dengan memilih media pembelajaran yang sesuai dengan materi dan karakteristik siswa, pemilihan bentuk penyajian media pembelajaran, membuat media dengan rancangan penyajian yang sudah disusun.

c. Tahap Develop (Pengembangan)

Pada tahap ini, konsep yang sudah disusun dalam tahap desain diwujudkan dalam produk (draf media pembelajaran berbentuk Fun Tax) untuk dilakukan penilaian oleh validator (ahli materi, ahli media, guru Administrasi Pajak) kemudian setelah direvisi, produk diuji coba secara terbatas pada siswa untuk mengetahui kelayakan media pembelajaran berbentuk Fun Tax sebagai media Pembelajaran Administrasi Pajak.

d. Tahap Disseminate (Penyebaran)

Tahap ini merupakan tahapan penggunaan produk (media pembelajaran berbentuk Fun Tax) yang telah dikembangkan pada skala yang lebih luas (diproduksi dalam jumlah 
besar). Penyebaran produk dilakukan di lingkungan SMK Negeri 1 Depok dan sekitarnya yang akan digunakan untuk kegiatan pembelajaran Administrasi Pajak Siswa Kelas XI Akuntansi.

\section{Teknik Pengumpulan Data}

Teknik pengumpulan data pada penelitian ini adalah menggunakan angket atau kuesioner. Kuesioner merupakan teknik pengumpulan data yang dilakukan dengan cara memberi seperangkat pertanyaan atau pernyataan tertulis kepada responden untuk dijawabnya (Sugiyono, 2015: 199). Kuesioner pada penelitian pengembangan ini digunakan untuk memperoleh data dari ahli media, ahli materi, guru dan siswa untuk menilai media pembelajaran yang telah dikembangkan.

\section{Teknik Analisis Data}

Teknik analisis data yang digunakan dalam penelitian ini adalah analisis data kualitatif dan kuantitatif dari hasil angket penilaian Media Pembelajaran Fun Tax oleh Ahli Materi, Ahli Media, dan Guru. Data kualitatif dalam penelitian ini merupakan data berupa kritik, saran dan komentar mengenai media pembelajaran yang diperoleh dari ahli media, ahli materi dan Guru. Data kuantitatif diperoleh dari kuisoner yang dikonversikan ke data kualitatif dengan skala 5 (skala likert) untuk mengetahui kualitas produk melalui langkah-langkah berikut:

a. Menentukan pemberian skor terhadap kelayakan media

Tabel 1. Ketentuan Pemberian Skor

\begin{tabular}{lc}
\hline Kriteria & Skor \\
\hline Sangat Layak & 5 \\
\hline Layak & 4 \\
\hline Cukup Layak & 3 \\
\hline Kurang Layak & 2 \\
\hline Tidak Layak & 1 \\
\hline
\end{tabular}

Sumber: Eko Putro Widoyoko (2013:106)

b. Melakukan tabulasi/ rekapitulasi data hasil penelitian
Menghitung rata-rata skor tiap aspek (indikator) dengan rumus:

$$
\begin{aligned}
\mu & =\frac{\Sigma x}{N} \\
\mu & =\text { skor rata-rata } \\
\Sigma \mathrm{X} & =\text { jumlah skor } \\
N & =\text { jumlah subjek uji coba }
\end{aligned}
$$

c. Menjumlah rerata skor tiap aspek

Tabel 2. Pedoman Konversi Data Kuantitatif ke Data Kualitatif Skala Lima

\begin{tabular}{lccl}
\hline \multicolumn{1}{c}{ Kategori } & Nilai & Rumus & Rentang \\
\hline Sangat Layak & $\mathrm{A}$ & $X>\bar{X} i+1,80 S B i$ & $\bar{X}>4,2$ \\
\hline Layak & $\mathrm{B}$ & $\bar{X} i+0,60 S B i<X \leq \bar{X} i+1,80 S B i$ & $3,4<\bar{X} \leq 4,2$ \\
\hline Cukup Layak & $\mathrm{C}$ & $\bar{X} i-0,60 S B i<X \leq \bar{X} i+1,60 S B i$ & $2,6<\bar{X} \leq 3,4$ \\
\hline Kurang Layak & $\mathrm{D}$ & $\bar{X} i-1,80 S B i<X \leq \bar{X} i-1,60 S B i$ & $1,8<\bar{X} \leq 2,6$ \\
\hline Sangat Kurang Layak & $\mathrm{E}$ & $X<\bar{X} i-1,80 S B i$ & $\bar{X} \leq 1,8$ \\
\hline
\end{tabular}

Keterangan:

$X \quad$ : Skor aktual

$\bar{X}_{\iota} \quad$ : rerata skor ideal

: $1 / 2$ (skor maksimal ideal + skor minimal ideal)

$: 1 / 2(5+1)$

$: 3$

$\mathrm{SBi} \quad$ : Simpangan Baku Ideal

: 1/6 (Skor maksimal - skor minimal ideal)

: $1 / 6(5-1)$

: 0,67

Sumber: Sukardjo (2005:53) dengan modifikasi.

\section{HASIL PENELITIAN DAN PEMBA-} HASAN

Pengembangan Fun Tax Berbasis Ular Tangga sebagai Media Pembelajaran Administrasi Pajak

1. Define (Pendefinisian)

Pada tahap ini, dilakukan kegiatan untuk menetapkan dan mendefinisikan syarat-syarat pengembangan. Secara umum, dalam tahap pendefinisian ini dilakukan dengan tujuan untuk memenuhi kebutuhan pengembangan. Pada tahap pendefinisian ini dilakukan dengan:

a. Analisis Kurikulum

Analisis kurikulum dilakukan dengan mempelajari kurikulum 
yang ada di SMK Negeri 1 Depok Yogyakarta. Hal ini dilakukan agar produk yang dihasilkan tidak menyimpang dari tujuan pembelajaran yang terdapat dalam standar kompetensi. Pada analisis kurikulum ini, peneliti melakukan analisis Kompetensi Inti (KI) dan Kompetensi Dasar (KD) pada Kurikulum 2013. Berdasarkan analisis KI dan KD serta rekomendasi guru Administrasi Pajak SMK Negeri 1 Depok, peneliti memilih materi umum Pajak Penghasilan yang dikembangkan dalam media Fun Tax. Adapun kurikulum yang digunakan adalah Kurikulum 2013, sehingga materi yang disajikan dalam media Fun Tax mengarahkan peserta didik pada proses pembelajaran yang menyenangkan.

b. Analisis Karakteristik Siswa

Karakter siswa dapat ditunjukkan dari hasil observasi dan wawancara yang telah dilakukan pada siswa kelas XI Akuntansi SMK Negeri 1 Depok Yogyakarta. Berdasarkan observasi dan wawancara, diketahui bahwa siswa kelas XI Akuntansi SMK Negeri 1 Depok Yogyakarta mengalami kendala atau kesulitan dalam mencerna materi berkarakteristik teori. Hal tersebut ditunjukkan pada permintaan siswa untuk dijelaskan kembali materi berkarakteristik teori sebelum diadakan ulangan atau ujian. Siswa juga mudah mengalami kebosanan dan menyukai hal-hal baru, karakter ini tercermin dari sudah cukup bermacamnya media yang telah digunakan guru dalam menyampaikan materi, namun masih meninggalkan kesan kurang variatif. Disisi lain, hubungan antarsiswa kelas XI Akuntansi sangat kompak, namun juga kompetitif. Berdasarkan informasi tersebut, maka perlu dikembangkan media pembelajaran yang inovatif, yang dapat meminimalisir rasa bosan siswa, dan semakin merekatkan hubungan siswa namun tetap mengedepankan kompetisi yang sehat. Sehingga pengembangan media berbasis permainan dapat menjadi salah satu solusi dalam permasalahan pembelajaran Administrasi Pajak.

c. Analisis Materi

Analisis Materi dilakukan dengan melakukan analisis silabus dan konsultasi bersama Guru Administrasi Pajak SMK Negeri 1 Depok. Pemilihan materi pokok dari materi umum Pajak Penghasilan yang dikembangkan dalam media Fun Tax yaitu.

1) Definisi dan dasar hukum pajak penghasilan $(\mathrm{PPh})$.

2) Pengertian dan pengelompokan subjek pajak

3) Kewajiban pajak subjektif

4) Pengecualian subyek pajak

5) Pengertian objek pajak penghasilan

6) Bukan objek pajak penghasilan

7) Objek pajak penghasilan bentuk usaha tetap

8) Pengurangan atau biaya yang diperkenankan dikurangi dari penghasilan bruto

9) Pengurangan atau biaya yang tidak diperkenankan dikurangi dari penghasilan bruto

d. Merumuskan Tujuan Media pembelajaran yang dikembangkan diharapkan dapat memenuhi kebutuhan siswa kelas XI Akuntansi SMK Negeri 1 Depok. 
2. Design (Perancangan)

Berdasarkan tahap yang telah dilakukan sebelumnya, yakni tahap pendefinisian (define) diperoleh beberapa informasi antara lain media yang akan dikembangkan adalah berbasis permainan yaitu Fun Tax berbasis ular tangga sebagai media pembelajaran Administrasi Pajak. Fun Tax dirancang dengan tampilan yang menarik. Di dalam media ini berisi pertanyaan-pertanyaan atau soal mengenai materi umum Pajak Penghasilan. Komponen media pembelajaran Fun Tax terdiri dari papan Fun Tax berukuran $49 \mathrm{cmx} 49 \mathrm{~cm}$ dengan 75 kartu soal yang terdiri dari 25 soal kuning, 25 soal hijau, dan 25 soal merah, 75 kartu bintang yang terdiri dari 25 bintang kuning, 25 bintang hijau, dan 25 bintang merah, 15 kartu Kamu Harus Ingat!, tokoh pion sebanyak pemain, dan sebuah dadu. Fun Tax diharapkan dapat menjadi media pembelajaran Administrasi Pajak yang dapat digunakan baik di dalam maupun luar kelas.

Tahapan dalam pembuatan media pembelajaran Fun Tax adalah sebagai berikut.

1) Perancangan Konsep Fun Tax

Konsep Fun Tax merupakan penerapan permainan ular tangga yang dimodifikasi. Adapun modifikasi yang terdapat dalam Fun Tax antara lain adalah desain papan, penambahan kartu soal yang memuat materi Pajak Penghasilan, kartu bintang, kartu Kamu Harus Ingat!, bentuk pion, dan cara permainan yang sedikit berbeda.

2) Penyusunan Materi Pajak Penghasilan

Setelah konsep Fun Tax terancang, peneliti menyusun materi yang akan dimasukkan ke dalam permainan. Materi yang masuk dalam Fun Tax disesuaikan dengan Kompetensi Dasar beserta indikator dan tujuan pembelajaran. Materimateri tersebut antara lain mengenai Pajak Penghasilan sampai dengan Beban yang Diperbolehkan mengurangi Penghasilan Bruto (Deductable Expenses) dan Beban yang Tidak Diperbolehkan mengurangi Penghasilan Bruto (Non Deductable Expenses).

3) Penyusunan Instrumen Angket Penilaian Produk

Instrumen angket penilaian ini diajukan kepada Ahli Materi (Dosen Akuntansi FE UNY), Ahli Media (Dosen Pendidikan Akuntansi FE UNY), Guru Administrasi Pajak SMK (Guru SMK Negeri 1 Depok Yogyakarta), dan siswa (Siswa kelas XI Akuntansi SMK Negeri 1 Depok Yogyakarta).

\section{Development (Pengembangan)}

Pada tahap Develompent (Pengembangan), Thiagarajan (1974:7) membagi dalam dua kegiatan yaitu expert appraisal dan developmental testing. Expert appraisal merupakan teknik untuk memvalidasi atau menilai kelayakan rancangan produk yang dilakukan oleh para Ahli. Saran-saran diberikan untuk memperbaiki materi dan rancangan media yang telah disusun. Developmental testing merupakan kegiatan menguji rancangan produk pada sasaran subjek yang sesungguhnya. Tahap ini dilakukan untuk mendapatkan respon.

Hasil penilaian kelayakan media dari Para Ahli adalah sebagai berikut:

Tabel 3. Hasil Penilaian Fun Tax oleh Ahli Materi

\begin{tabular}{ccccc}
\hline No & $\begin{array}{c}\text { Aspek } \\
\text { Penilaian }\end{array}$ & $\begin{array}{c}\text { Total } \\
\text { Skor }\end{array}$ & $\begin{array}{c}\text { Rata- } \\
\text { rata }\end{array}$ & Kategori \\
\hline 1. & Pembelajaran & 72 & 4,5 & $\begin{array}{c}\text { Sangat } \\
\text { Layak }\end{array}$ \\
\hline
\end{tabular}


Tabel 4. Hasil Penilaian Fun Tax oleh Ahli Media

\begin{tabular}{clccc}
\hline No & $\begin{array}{c}\text { Aspek } \\
\text { Penilaian }\end{array}$ & $\begin{array}{c}\text { Total } \\
\text { Skor }\end{array}$ & $\begin{array}{c}\text { Rata- } \\
\text { rata }\end{array}$ & Kategori \\
\hline 1. & $\begin{array}{l}\text { Rekayasa } \\
\text { Media }\end{array}$ & 32 & 4,57 & $\begin{array}{l}\text { Sangat } \\
\text { Layak }\end{array}$ \\
\hline 2 & $\begin{array}{l}\text { Komunikasi } \\
\text { Visual }\end{array}$ & 59 & 4,53 & $\begin{array}{l}\text { Sangat } \\
\text { Layak }\end{array}$ \\
\hline Total & 91 & 4,55 & $\begin{array}{l}\text { Sangat } \\
\text { Layak }\end{array}$ \\
\hline
\end{tabular}

Tabel 5. Hasil Penilaian Fun Tax oleh Guru Administrasi Pajak

\begin{tabular}{clccc}
\hline No & $\begin{array}{c}\text { Aspek } \\
\text { Penilaian }\end{array}$ & $\begin{array}{c}\text { Total } \\
\text { Skor }\end{array}$ & $\begin{array}{c}\text { Rata- } \\
\text { rata }\end{array}$ & Kategori \\
\hline 1. & Pembelajaran & 42 & 4,67 & $\begin{array}{l}\text { Sangat } \\
\text { Layak }\end{array}$ \\
\hline 2. & $\begin{array}{l}\text { Rekayasa } \\
\text { Media }\end{array}$ & 24 & 4,8 & $\begin{array}{l}\text { Sangat } \\
\text { Layak }\end{array}$ \\
\hline 3. & $\begin{array}{l}\text { Komunikasi } \\
\text { Visual }\end{array}$ & 24 & 4,8 & $\begin{array}{l}\text { Sangat } \\
\text { Layak }\end{array}$ \\
\hline Total & 90 & 4,74 & $\begin{array}{l}\text { Sangat } \\
\text { Layak }\end{array}$ \\
\hline
\end{tabular}

Tabel 6. Hasil Penilaian Para Ahli

\begin{tabular}{llcccccc}
\hline No & $\begin{array}{c}\text { Aspek } \\
\text { Penilaian }\end{array}$ & $\begin{array}{c}\text { Ahli } \\
\text { Materi }\end{array}$ & $\begin{array}{c}\text { Ahli } \\
\text { Media }\end{array}$ & Guru & $\begin{array}{c}\text { Rata- } \\
\text { rata }\end{array}$ & Nilai & Kategor \\
\hline 1. & Pembelajaran & 4,5 & & 4,67 & 4,58 & A & $\begin{array}{c}\text { Sangat } \\
\text { Layak }\end{array}$ \\
\hline 2. & $\begin{array}{l}\text { Rekayasa } \\
\text { Media }\end{array}$ & 4,57 & 4,8 & 4,68 & A & $\begin{array}{c}\text { Sangat } \\
\text { Layak }\end{array}$ \\
\hline 3. & $\begin{array}{l}\text { Komunikasi } \\
\text { Visual }\end{array}$ & 4,53 & 4,8 & 4,66 & A & $\begin{array}{c}\text { Sangat } \\
\text { Layak }\end{array}$ \\
\hline & Rerata Skor Keseluruhan (X) & & $\mathbf{4 , 6 4}$ & A & $\begin{array}{c}\text { Sangat } \\
\text { Layak }\end{array}$ \\
\hline
\end{tabular}

Setelah produk divalidasi oleh Para Ahli, selanjutnya produk dilakukan uji pengembangan kepada 28 siswa kelas XI Akuntansi 1 SMK Negeri 1 Depok. Adapun hasil dari uji pengembangan adalah sebagai berikut:

Tabel 7. Hasil Uji Pengembangan

\begin{tabular}{llcc}
\hline No & Aspek Penilaian & $\begin{array}{c}\text { Total } \\
\text { Skor }\end{array}$ & Rata-rata \\
\hline 1. & Pembelajaran & 703 & 4,18 \\
\hline 2. & Rekayasa Media & 481 & 4,29 \\
\hline 3. $\quad$ Komunikasi Visual & 843 & 4,30 \\
\hline Total & 2027 & 4,26 \\
\hline Kategori & \multicolumn{2}{c}{ Sangat Layak } \\
\hline
\end{tabular}

4. Disseminate (Penyebaran)

Setelah media dilakukan validasi, maka langkah selanjutnya adalah penyebaran Fun Tax ke beberapa sekolah, diantaranya SMK
YPPK 2 Sleman Yogyakarta dan SMK Sriwijaya 2 Wangon. Adapun pendapat dari guru sekolah tersebut adalah bahwa Fun Tax yang telah dikembangkan cukup menarik, dapat menjadi variasi media pembelajaran dari yang sudah ada, dan perlu dikembangkan lagi untuk materi ataupun mata pelajaran yang lain.

\section{SIMPULAN DAN SARAN \\ Simpulan}

Berdasarkan penelitian dan pengembangan Fun Tax sebagai media pembelajaran Administrasi Pajak dengan materi Pajak Penghasilan maka dapat disimpulkan beberapa hal sebagai berikut.

a. Fun Tax sebagai media pembelajaran Administrasi Pajak dikembangkan dengan menggunakan model pengembangan Four-D (4D) melalui 4 tahapan, yaitu pendefinisian (define), perancangan (define), pengembangan (develop), dan penyebaran (disseminate). Pada tahap define, peneliti melakukan observasi dan wawancara yang selanjutnya dilakukan analisis kebutuhan yang meliputi analisis kurikulum, analisis karakteristik siswa, analisis materi, serta merumuskan tujuan. Pada tahap define diperoleh informasi bahwasanya siswa membutuhkan media yang inovatif dan berbasis permainan, sehingga dipilih media pembelajaran Fun Tax berbasis permainan Ular Tangga. Selanjutnya, pada tahap design dilakukan dengan menetapkan media pembelajaran yang akan dikembangkan, merancang penyajian media, dan membuat media. Pada tahap develop, media yang telah dibuat dinilai oleh para validator yang terdiri dari Ahli Materi, Ahli Media, dan Guru. Media juga dilakukan uji pengembangan terhadap siswa. Pada tahap terakhir yaitu disseminate, media telah disebarkan di dua sekolah, yaitu 
SMK YPKK 2 Sleman dan SMK Sriwijaya 2 Wangon.

b. Kelayakan Fun Tax telah dinilai oleh Ahli Materi dengan rata-rata skor 4,5 dengan kategori Sangat Layak, penilaian Ahli Media dengan rata-rata skor 4,55 dalam kategori Sangat Layak, dan penilaian oleh Guru Administrasi Pajak dengan rata-rata skor 4,74. Penilaian yang telah dilakukan oleh para Ahli dan praktisi memperoleh ratarata skor 4,64 dengan kategori Sangat Layak. Adapun respon siswa mengenai Fun Tax menunjukkan rata-rata skor sebesar 4,26 yang berarti masuk pada kategori Sangat Layak.

\section{Saran}

Berdasarkan penelitian pengembangan dan keterbatasan penelitian Fun Tax sebagai media pembelajaran Administrasi Pajak, peneliti memberikan saran pemanfaatan dan pengembangan media lebih lanjut sebagai berikut.

a. Media Fun Tax yang telah dikembangkan diharapkan dapat disebarkan secara luas pada sekolahsekolah berkarakteristik sama dengan sekolah penelitian.

b. Guru diharapkan dapat menjadikan Fun Tax, sebagai salah satu alternatif media pembelajaran Administrasi Pajak untuk meminimalisir kejenuhan siswa dalam pembelajaran yang dirasa cenderung monoton.

c. Pengembangan Fun Tax perlu dilakukan untuk materi Administrasi Pajak pada Kompetensi Dasar lainnya yang memiliki karakteristik sama.

\section{DAFTAR PUSTAKA}

Ahsan Akhtar dkk. 2018. Use of

Media for Effective Instruction its Importance: Some Consideration dalam Journal of Elementary Education. University of the Punjb:

A Publication of Deptt. Of Elementary Education. Vol. 18 (1-2) 34-40.
Shah, K.A. (2017). Game Based Accounting Learning: The Impact of Games in Learning Introductory Accounting. International Journal of Information System In the Service Sector, 9 (4), 21-29. Diakses dari https://eresources.perpusnas.go.id:2191/gate way/article/full-text-pdf/190428 pada tanggal 7 Mei 2018 pukul 11.50

Thiagarajan, S, Semmel, D.S, Semmel, M. I. (1974). Instructional Development for Training Teacher of Exceotional Children. United State: University of Minnesota.

Undang-Undang Nomor 20 Tahun 2003 tentang Sistem Pendidikan Nasional.Kementrian Pendidikan Nasional.

United Nations Educational, Scientific, and Cultural Organization.2015. The EFA

Development Index (EDI) and Its Components.Diambil pada tanggal 20 Februari 2018. Dari https://en.unesco.org/gemreport/education-all-developmentindex 